University of Nebraska - Lincoln

DigitalCommons@University of Nebraska - Lincoln

\title{
Acquisition and Evaluation of Thermodynamic Data for Morenosite-Retgersite Equilibria at 0.1 MPa
}

\author{
I-Ming Chou \\ 954 National Center, U.S. Geological Survey, Reston, Virginia 20192, U.S.A., imchou@usgs.gov \\ Robert R. Seal II \\ 954 National Center, U.S. Geological Survey, Reston, Virginia 20192, U.S.A.
}

Follow this and additional works at: https://digitalcommons.unl.edu/usgsstaffpub

Part of the Earth Sciences Commons

Chou, I-Ming and Seal II, Robert R., "Acquisition and Evaluation of Thermodynamic Data for MorenositeRetgersite Equilibria at 0.1 MPa" (2003). USGS Staff -- Published Research. 328.

https://digitalcommons.unl.edu/usgsstaffpub/328

This Article is brought to you for free and open access by the US Geological Survey at DigitalCommons@University of Nebraska - Lincoln. It has been accepted for inclusion in USGS Staff -- Published Research by an authorized administrator of DigitalCommons@University of Nebraska - Lincoln. 


\title{
Acquisition and evaluation of thermodynamic data for morenosite-retgersite equilibria at 0.1 MPa
}

\author{
I-Ming CHOU* AND RobERT R. SEAL II
}

954 National Center, U.S. Geological Survey, Reston, Virginia 20192, U.S.A.

\begin{abstract}
Metal-sulfate salts in mine drainage environments commonly occur as solid solutions containing $\mathrm{Fe}, \mathrm{Cu}, \mathrm{Mg}, \mathrm{Zn}, \mathrm{Al}, \mathrm{Mn}, \mathrm{Ni}, \mathrm{Co}, \mathrm{Cd}$, and other elements. Thermodynamic data for some of the endmember salts containing $\mathrm{Fe}, \mathrm{Cu}, \mathrm{Zn}$, and $\mathrm{Mg}$ have been collected and evaluated previously, and the present study extends to the system containing Ni. Morenosite $\left(\mathrm{NiSO}_{4} \cdot 7 \mathrm{H}_{2} \mathrm{O}\right)$-retgersite $\left(\mathrm{NiSO}_{4} \cdot 6 \mathrm{H}_{2} \mathrm{O}\right)$ equilibria were determined along five humidity buffer curves at $0.1 \mathrm{MPa}$ and between 5 and $22{ }^{\circ} \mathrm{C}$. Reversals along these humidity-buffer curves yield $\ln K=17.58-6303.35 / T$, where $K$ is the equilibrium constant, and $T$ is temperature in $\mathrm{K}$. The derived standard Gibbs free energy of reaction is 8.84 $\mathrm{kJ} / \mathrm{mol}$, which agrees very well with the values of $8.90,8.83$, and $8.85 \mathrm{~kJ} / \mathrm{mol}$ based on the vapor pressure measurements of Schumb (1923), Bonnell and Burridge (1935), and Stout et al. (1966), respectively. This value also agrees reasonably well with the values of 8.65 and $9.56 \mathrm{~kJ} / \mathrm{mol}$ calculated from the data compiled by Wagman et al. (1982) and DeKock (1982), respectively. The temperaturehumidity relationships defined by this study for dehydration equilibria between morenosite and retgersite explain the more common occurrence of retgersite relative to morenosite in nature.
\end{abstract}

\section{INTRODUCTION}

Efflorescent metal-sulfate salts have been demonstrated to play an important role in metal cycling in acid mine-drainage environments (Dagenhart 1980; Jambor et al. 2000). The salts form through evaporative processes in all climates and provide a means of storing acidity and metals. Their rapid and high solubilities cause acute toxic effects to aquatic ecosystems during spring-melt events in areas with winter snow cover, and during rainstorm events.

Efflorescent sulfate salts of $\mathrm{Fe}$ - both $\mathrm{Fe}^{2+}$ and $\mathrm{Fe}^{3+}$ - such as melanterite $\left[\mathrm{Fe}^{2+} \mathrm{SO}_{4} \cdot 7 \mathrm{H}_{2} \mathrm{O}\right]$, rozenite $\left[\mathrm{Fe}^{2+} \mathrm{SO}_{4} \cdot 4 \mathrm{H}_{2} \mathrm{O}\right]$, and copiapite $\left[\mathrm{Fe}^{2+} \mathrm{Fe}^{3+}{ }_{4}\left(\mathrm{SO}_{4}\right)_{6}(\mathrm{OH})_{2} \cdot 20 \mathrm{H}_{2} \mathrm{O}\right]$, and salts of $\mathrm{Al}$, such as alunogen $\left[\mathrm{Al}_{2}\left(\mathrm{SO}_{4}\right)_{3} \cdot 17 \mathrm{H}_{2} \mathrm{O}\right]$ and halotrichite-pickeringite $\left[\left(\mathrm{Fe}^{2+}, \mathrm{Mg}\right) \mathrm{Al}_{2}\left(\mathrm{SO}_{4}\right)_{4} \cdot 22 \mathrm{H}_{2} \mathrm{O}\right]$, are common in mine-waste settings. However, salts dominated by other, less abundant metals such as $\mathrm{Cu}, \mathrm{Zn}, \mathrm{Ni}$, and others also occur locally (Jambor et al. 2000). More important from an environmental perspective, toxic trace metals commonly occur in solid solution in the more common hydrated $\mathrm{Fe}$-sulfate salts such as melanterite, rozenite, or the $\mathrm{Fe}^{2+}$ sulfate pentahydrate-siderotil. Melanterite has been documented experimentally and in nature containing close to 45 $\mathrm{mol} \% \mathrm{Cu}, 40 \mathrm{~mol} \% \mathrm{Zn}$, and $20 \mathrm{~mol} \% \mathrm{Ni}$ (Jambor et al. 2000).

The ability to model the geochemical behavior of these minerals and their trace elements in aquatic environments relies on the availability of accurate and precise thermodynamic data for these phases and their solid solutions. The ability to model solid solutions depends not only on reliable data for the mixing properties of these minerals, but also on the data for endmember compositions of hydrated trace metal sulfates. Thermodynamic data for many of these minerals have not been available, or were of poor quality until recently. For all of these

\footnotetext{
*E-mail:imchou@usgs.gov
}

systems, such as the $\mathrm{Fe}^{2+} \mathrm{SO}_{4}-\mathrm{H}_{2} \mathrm{O}$ system, temperature-dependent equilibria among four or more solids can be described by simple dehydration reactions. Thus, recent development of the humidity-buffer technique provides an efficient and reliable method for obtaining and evaluating these data (Chou et al. 2002). To establish a useful thermodynamic database for the interpretation of natural assemblages, it is first necessary to study thermodynamic properties of end-member sulfate salts (Chou et al. 2000, 2002 for $\mathrm{Fe}$ and $\mathrm{Cu}$; Chou and Seal 2001a, in preparation, for $\mathrm{Zn}$; and Chou and Seal 2001b, 2003, for $\mathrm{Mg}$ ). The present study extends the database to the Ni sulfate system. Dissolved Ni has known toxicity to aquatic ecosystems in a variety of mine drainage settings.

\section{Mineralogy of nickel sulfates}

Morenosite is a member of the epsomite group, which consists of orthorhombic $\left(P 2_{1} 2_{1} 2_{1}\right)$ sulfate heptahydrate minerals of the type $\mathrm{M}^{2+} \mathrm{SO}_{4} \cdot 7 \mathrm{H}_{2} \mathrm{O}$, where $\mathrm{M}$ represents $\mathrm{Mg}$ (epsomite), $\mathrm{Ni}$ (morenosite), and $\mathrm{Zn}$ (goslarite). In contrast, the common $\mathrm{Fe}^{2+}$ sulfate heptahydrate, melanterite $\left[\mathrm{FeSO}_{4} \cdot 7 \mathrm{H}_{2} \mathrm{O}\right]$, is monoclinic. Morenosite apparently forms complete solid solutions with the Mg and Zn end-members (Jambor et al. 2000). In the presence of an aqueous solution, morenosite is not stable at temperatures above about $31.2{ }^{\circ} \mathrm{C}$ and dehydrates to form retgersite (Linke and Seidell 1965).

Retgersite $\left[\alpha-\mathrm{NiSO}_{4} \cdot 6 \mathrm{H}_{2} \mathrm{O}\right]$ is bluish green and tetragonal in crystal form. It is stable between 31.2 and $53.3{ }^{\circ} \mathrm{C}$ (Linke and Seidell 1965). Above $53.3^{\circ} \mathrm{C}$, the crystals turn green and form nickelhexahydrite $\left[\beta-\mathrm{NiSO}_{4} \cdot 6 \mathrm{H}_{2} \mathrm{O}\right]$. Nickelhexahydrite is one of the six members of the hexahydrite group, which are monoclinic $(C 2 / c)$ sulfate minerals of the type $\mathrm{M}^{2+} \mathrm{SO}_{4} \cdot 6 \mathrm{H}_{2} \mathrm{O}$, where $\mathrm{M}$ represents $\mathrm{Mg}$ (hexahydrite), $\mathrm{Mn}$ (chvaleticeite), $\mathrm{Fe}$ (ferrohexahydrite), $\mathrm{Ni}$ (nickelhexahydrite), Co (moorhouseite), and $\mathrm{Zn}$ (bianchite). Even though little is 
known about the limits of solid solution in these hexahydrates, substitution of up to $27 \mathrm{~mol} \% \mathrm{Ni}$ for $\mathrm{Mg}$ has been reported for natural hexahydrite (Janjic et al. 1980). Except for hexahydrite, minerals of the group occur sparingly as the oxidation products of sulfide deposits (Jambor et al. 2000).

\section{Dehydration equilibrium}

The stability of morenosite and retgersite can be related by the reaction:

$$
\begin{aligned}
& \mathrm{NiSO}_{4} \cdot 7 \mathrm{H}_{2} \mathrm{O}_{(\mathrm{s})}= \\
& \text { morenosite }
\end{aligned}
$$

where (s) and (g) are solid and gas, respectively. Published estimates for the equilibrium relative humidity $(\mathrm{RH})$ at $25{ }^{\circ} \mathrm{C}$ range from 67 to $96 \%$ for the reaction. To evaluate these data, the humidity-buffer technique (Polyanskii et al. 1976; Malinin et al. 1977, 1979; Chou et al. 1998a, 1998b, 1999, Chou et al. 2002) was used in this study to determine equilibrium constants for this reaction between 5 and $22{ }^{\circ} \mathrm{C}$ at $0.1 \mathrm{MPa}$. Reversals were obtained along five humidity-buffer curves. This technique has been applied to determine the equilibria between melanterite $\left[\mathrm{Fe}^{2+} \mathrm{SO}_{4} \cdot 7 \mathrm{H}_{2} \mathrm{O}\right]$ and rozenite $\left[\mathrm{Fe}^{2+} \mathrm{SO}_{4} \cdot 4 \mathrm{H}_{2} \mathrm{O}\right]$ (Chou et al. 2002), chalcanthite $\left[\mathrm{CuSO}_{4} \cdot 5 \mathrm{H}_{2} \mathrm{O}\right]$ and bonattite $\left[\mathrm{CuSO}_{4} \cdot 3 \mathrm{H}_{2} \mathrm{O}\right]\left(\right.$ Chou et al. 2002), goslarite $\left[\mathrm{ZnSO}_{4} \cdot 7 \mathrm{H}_{2} \mathrm{O}\right]$ and bianchite $\left[\mathrm{ZnSO}_{4} \cdot 6 \mathrm{H}_{2} \mathrm{O}\right.$ ] (Chou and Seal 2003), and epsomite $\left[\mathrm{MgSO}_{4} \cdot 7 \mathrm{H}_{2} \mathrm{O}\right]$ and hexahydrite $\left[\mathrm{MgSO}_{4} \cdot 6 \mathrm{H}_{2} \mathrm{O}\right]$ (Chou and Seal, in preparation). It should be emphasized that Reaction 1 of this study does not involve an aqueous phase. However, as will be presented later, in the presence of an additional aqueous phase at equilibrium at $0.1 \mathrm{MPa}$, the system becomes invariant with defined equilibrium temperature and humidity.

The standard Gibbs free energy of reaction, $\Delta G_{\mathrm{r}}^{0}$, for Reaction 1 was then derived from the equilibrium constant, $K$, using the relation:

$$
\begin{aligned}
& \Delta G_{\mathrm{r}}^{0}=-\mathrm{R} T \ln K=-\mathrm{R} T \ln \left(a_{\mathrm{H}_{2} \mathrm{O}}\right)=-\mathrm{R} T \ln \left(f_{\mathrm{H}_{2} \mathrm{O}} / 0.1\right)= \\
& -\mathrm{R} T \ln \left[\left(f_{\mathrm{H}_{2} \mathrm{O}} / 0.1\right) \cdot(\% R H) / 100\right],
\end{aligned}
$$

where $\mathrm{R}$ is the gas constant $(8.31451 \mathrm{~J} / \mathrm{molK}) ; T$ is absolute temperature; $a_{\mathrm{H}_{2} \mathrm{O}}$ is the activity of $\mathrm{H}_{2} \mathrm{O} ; f_{\mathrm{H}_{2} \mathrm{O}}$ is the equilibrium $\mathrm{H}_{2} \mathrm{O}$ fugacity (in MPa); $f_{\mathrm{H}_{2} \mathrm{O}}^{*}$ is the fugacity of pure $\mathrm{H}_{2} \mathrm{O}$ (in $\mathrm{MPa}$ ) and $R H$ is the relative humidity. The standard states for minerals and $\mathrm{H}_{2} \mathrm{O}$ are pure solids and $\mathrm{H}_{2} \mathrm{O}$, respectively, at 0.1 $\mathrm{MPa}$ and temperature. Preliminary results were presented by Chou and Seal (2002).

\section{Previous work}

Figure 1 summarizes all previous and current data related to the morenosite-retgersite equilibria in terms of temperature and relative humidity. Vapor-pressure measurements were made at $0.1 \mathrm{MPa}$ and $25^{\circ} \mathrm{C}$ by Schumb (1923), between 10 and 25 ${ }^{\circ} \mathrm{C}$ by Bonnell and Burridge (1935), and between 20 and $30^{\circ} \mathrm{C}$ by Stout et al. (1966). Thermodynamic data for morenosite and retgersite derived from calorimetric measurements were evaluated and compiled by Wagman et al. (1982) and DeKock (1982), and the morenosite-retgersite phase boundaries based on these data are shown in Figure 1.

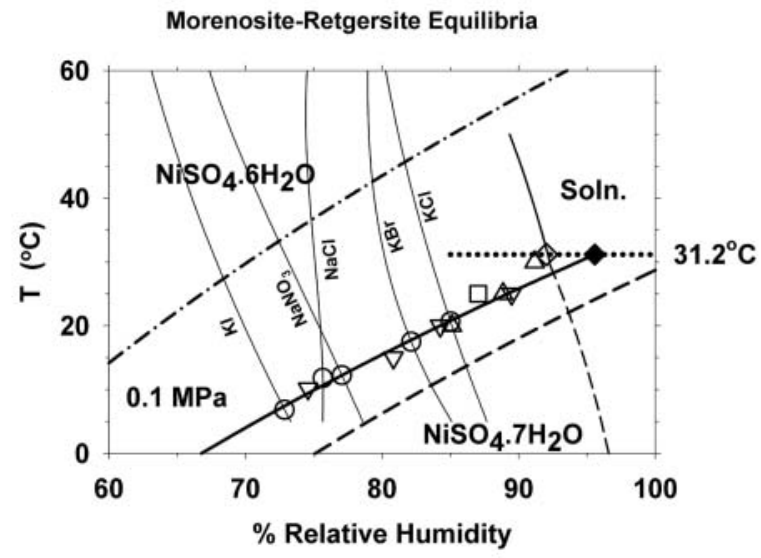

FIGURE 1. Morenosite $\left[\mathrm{NiSO}_{4} \cdot 7 \mathrm{H}_{2} \mathrm{O}\right]$-retgersite $\left[\mathrm{NiSO}_{4} \cdot 6 \mathrm{H}_{2} \mathrm{O}\right]$ equilibria at $0.1 \mathrm{MPa}$. Result of vapor-pressure measurement at 0.1 $\mathrm{MPa}$ and $25^{\circ} \mathrm{C}$ by Schumb (1923) is shown by the square. Also shown are those between 10 and $25^{\circ} \mathrm{C}$ by Bonnell and Burridge (1935; upright triangles), and between 20 and $30^{\circ} \mathrm{C}$ by Stout et al. (1966; downward triangles). The morenosite-retgersite phase boundary based on the thermodynamic data compiled by Wagman et al. (1982) and DeKock (1982) are represented by the thick dashed and dash-dot lines, respectively. Experimental results obtained in this study are shown by the large circles along five humidity-buffer cures (near-vertical thin solid lines), and the thick solid line is the least-squares fit for new experimental data. The equilibrium boundaries for morenosite-saturated and retgersite-saturated aqueous solutions are shown by the thin dashed and solid curves, respectively (Reardon 1989; personal communication, 2002). These data predict the invariant point for the assemblage morenosite + retgersite + aqueous solution + vapor at the invariant temperature of $31.2{ }^{\circ} \mathrm{C}$ (Linke and Seidell, 1965 ; horizontal dotted line) at $\% R H=92.0$ (open diamond). Our data predict the invariant point at $\% R H=95.6$, as shown by the solid diamond. For details, see text.

\section{EXPERIMENTAL METHOD AND RESULTS}

Starting materials were mixtures of reagent grade $\mathrm{NiSO}_{4} \cdot 6 \mathrm{H}_{2} \mathrm{O}$ (MERCK, Lot no. 42589) and its hydration product $\left[\mathrm{NiSO}_{4} \cdot 7 \mathrm{H}_{2} \mathrm{O}\right]$. A weighed amount of the starting material, typically 350 to $590 \mathrm{mg}$, was loaded into a plastic sample container $(8 \mathrm{~mm} \mathrm{ID} \times 10 \mathrm{~mm}$ OD and $20 \mathrm{~mm}$ tall $)$, which was partly immersed in a humidity-buffer solution in a glass container $(17.5 \mathrm{~mm} \mathrm{ID} \times 20 \mathrm{~mm}$ OD and $40 \mathrm{~mm}$ tall) sealed by a rubber stopper. Humidity-buffer solutions are saturated solutions with well-characterized humidity variations with temperature (Greenspan 1977; Chou et al. 2000, 2002). The present study used five different binary aqueous buffer solutions: $\mathrm{KI}, \mathrm{NaCl}, \mathrm{NaNO}_{3}, \mathrm{KBr}$, and $\mathrm{KCl}$ (Fig. 1). The whole assembly was then immersed in a water bath, the temperature of which was controlled to $\pm 0.03{ }^{\circ} \mathrm{C}$ and measured by a Pt resistance probe (accurate to $\pm 0.02{ }^{\circ} \mathrm{C}$ ). Small holes through the cap of the sample chamber allow the vapor phase of the sample to equilibrate with that of the buffer system at the fixed temperature. The direction of reaction was determined by the mass change of the sample (precise to $\pm 0.05 \mathrm{mg}$ ). Both the starting material and experimental products were examined by X-ray diffraction and optical methods, and no unexpected phases were identified. Uncertainties in predicted \% RH for the humidity buffers used in the temperature range of this study are no more than \pm 0.4 (Greenspan 1977). Experimental results are listed in Tables 1 and 2, and plotted in Figure 1. In Figure 1, the circle along each humidity buffer curve represents a reversal point, and the thick solid curve is the least-squares regression of these reversal points. Previous published results are also plotted for comparison.

\section{Thermodynamic analysis}

Equilibrium constants and $\Delta \mathrm{G}_{\mathrm{r}}^{0}$ values for Reaction 1 were obtained from our experimental data using Equation 2 and these values are listed in Tables 2 
TABLE 1. Experimental results at $0.1 \mathrm{MPa}$

\begin{tabular}{|c|c|c|c|c|c|}
\hline $\begin{array}{l}\text { Humidity } \\
\text { buffer }\end{array}$ & $\begin{array}{l}\text { eriment } \\
\text { no. }\end{array}$ & it $\begin{array}{c}T \\
\left({ }^{\circ} \mathrm{C}\right)^{*}\end{array}$ & $\begin{array}{l}\text { Mass of initial } \\
\text { sample }(\mathrm{mg}) \dagger\end{array}$ & $\begin{array}{l}\text { Duration } \\
\text { (h) }\end{array}$ & $\begin{array}{c}\text { Mass change } \\
(\mathrm{mg})\end{array}$ \\
\hline \multirow[t]{6}{*}{$\mathrm{KI}$} & 1 & $(6.45)$ & 351.81 & 72 & +0.09 \\
\hline & 2 & (6.45) & 373.97 & 72 & +0.28 \\
\hline & 3 & (7.22) & 351.90 & 98 & -0.12 \\
\hline & 4 & (7.22) & 374.25 & 98 & -0.03 \\
\hline & 5 & 8.84 & 354.44 & 72 & -0.40 \\
\hline & 6 & 8.84 & 377.02 & 72 & -0.63 \\
\hline \multirow[t]{6}{*}{$\mathrm{NaCl}$} & 1 & (11.57) & 515.35 & 67 & +0.61 \\
\hline & 2 & (11.57) & 588.77 & 67 & +0.49 \\
\hline & 3 & (12.04) & 515.35 & 97 & -0.09 \\
\hline & 4 & (12.04) & 588.88 & 97 & -0.07 \\
\hline & 5 & 12.45 & 515.96 & 69 & -0.61 \\
\hline & 6 & 12.45 & 589.26 & 69 & -0.46 \\
\hline \multirow[t]{10}{*}{$\mathrm{NaNO}_{3}$} & 1 & 10.46 & 355.71 & 68 & +0.49 \\
\hline & 2 & 10.46 & 377.43 & 68 & +0.42 \\
\hline & 3 & 11.57 & 356.20 & 67 & +0.22 \\
\hline & 4 & 11.57 & 377.85 & 67 & +0.20 \\
\hline & 5 & (12.04) & 355.62 & 95 & +0.47 \\
\hline & 6 & (12.04) & 368.38 & 95 & +0.14 \\
\hline & 7 & 12.04 & 356.27 & 97 & -0.08 \\
\hline & 8 & 12.04 & 377.92 & 97 & -0.02 \\
\hline & 9 & (12.45) & 356.42 & 69 & -0.15 \\
\hline & 10 & (12.45) & 378.05 & 69 & -0.13 \\
\hline \multirow[t]{9}{*}{$\mathrm{KBr}$} & 1 & 16.17 & 356.19 & 55 & +0.88 \\
\hline & 2 & 16.17 & 377.90 & 55 & +0.74 \\
\hline & 3 & (17.01) & 356.92 & 96 & +0.32 \\
\hline & 4 & (17.01) & 378.56 & 96 & +0.28 \\
\hline & 5 & (17.97) & 357.07 & 64 & -0.15 \\
\hline & 6 & (17.97) & 378.64 & 64 & -0.08 \\
\hline & 7 & 20.16 & 515.17 & 117 & -0.30 \\
\hline & 8 & 24.02 & 514.91 & 96 & -0.12 \\
\hline & 9 & 24.02 & 591.18 & 96 & -0.17 \\
\hline \multirow[t]{6}{*}{$\mathrm{KCl}$} & 1 & $(20.16)$ & 357.17 & 117 & +0.39 \\
\hline & 2 & (20.16) & 378.88 & 117 & +0.79 \\
\hline & 3 & (21.17) & 357.56 & 118 & -0.31 \\
\hline & 4 & (21.17) & 379.67 & 118 & -0.35 \\
\hline & 5 & 24.02 & 357.25 & 96 & -3.05 \\
\hline & 6 & 24.02 & 379.32 & 96 & -2.59 \\
\hline
\end{tabular}

* Values in parentheses were used to bracket the reaction. $\dagger$ Starting material consisted of a mixture of $\mathrm{NiSO}_{4} \cdot 7 \mathrm{H}_{2} \mathrm{O}$ and $\mathrm{NiSO}_{4} \cdot 6 \mathrm{H}_{2} \mathrm{O}$.

and 3. Figure 2 shows the relation between $\ln K$ and $1 / T$ for Reaction 1 ; our reversal data can be represented by $\ln K( \pm 0.013)=17.58-6303.35 / T$. The standard enthalpy of reaction, $\Delta H_{\mathrm{r}}^{0}$, was calculated according to the relation:

$\partial(\ln K) / \partial(1 / T)=-\Delta H_{\mathrm{r}}^{0} / \mathrm{R}$

The value of $\Delta H_{\mathrm{r}}^{0}$ for Reaction 1 is listed in Table 3, and the entropy of reaction, $\Delta S_{\mathrm{r}}^{0}$, was calculated from the relation:

$$
\Delta G_{\mathrm{r}}^{0}=\Delta H_{\mathrm{r}}^{0}-T \Delta S_{\mathrm{r}}^{0}
$$

and is also listed in Table 3. These derived thermodynamic data are compared with previous data in Table 3. Note that the uncertainties listed in Table 3 were derived from those associated with equilibrium temperatures and humidity buffers assuming no uncertainties for the vapor pressure of pure water.

Our data are in excellent agreement with all previous vapor pressure measurements (Schumb 1923; Bonnell and Burridge 1935; Stout et al. 1966), as shown in Table 3 and Figures 1 and 2. Also, our data agree reasonably well with the thermodynamic data compiled by Wagman et al. (1982), and those compiled by DeKock (1982). Our value for $\Delta G_{\mathrm{r}}^{0}$ is $0.2 \mathrm{~kJ} / \mathrm{mol}$ lower than the value reported by Wagman et al. (1982), and $0.7 \mathrm{~kJ} / \mathrm{mol}$ higher than the value of DeKock (1982); these differences are well within the uncertainties of their estimates.

\section{DISCUSSION}

To verify our experimental results, we compared the invariant point for the assemblage morenosite + retgersite + aqueous solution + vapor (MRAV) derived from our results with that predicted by Reardon (1989, and personal communication 2002). Previous observations (Linke and Seidell 1965 and ref-

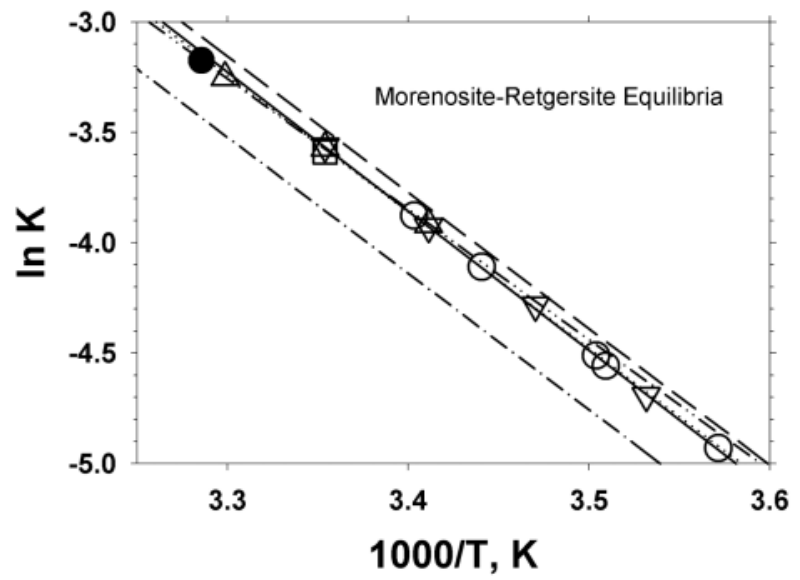

FIGURE 2. $\ln K$ vs. 1/T plot for the morenosite-retgersite equilibria at 0.1 MPa. Circles are current data from Table 2, and the solid line is a least-squares regression of the data. Previous datum at $25{ }^{\circ} \mathrm{C}$ reported by Schumb (1923) is shown by the square. The downward triangles between 10 and $25{ }^{\circ} \mathrm{C}$ represent the data of Bonnell and Burridge (1935), and upright triangles between 20 and $30{ }^{\circ} \mathrm{C}$ are the data of Stout et al. (1966). Also shown are regression lines based on the data of Bonnell and Burridge (1935; dotted), Stout et al. (1966; dash-dotdot), Wagman et al. (1982; dash), and DeKock (1982; dash-dot). The large filled circle at the upper left corner is the invariant point at $31.2{ }^{\circ} \mathrm{C}$ for the assemblage morenosite + retgersite + aqueous solution + vapor predicted from the model of Pitzer for the morenosite- and retgersite-saturated solution (Reardon 1989, and personal communication, 2002). For detail, see text.

erences therein) indicated that the temperature of the invariant point for the assemblage MRAV is most likely near $31.2{ }^{\circ} \mathrm{C}$ (horizontal dotted line in Fig. 1). Also shown in Figure 1 are the stability boundaries between morenosite and aqueous solution, and between retgersite and aqueous solution predicted by Reardon (personal communication, 2002) using the model of Pitzer (Reardon 1989). These boundaries indicate the $\% R H$ for the MRAV invariant point at $31.2{ }^{\circ} \mathrm{C}$ is 92.0 , which compares reasonable well with the value of 95.6 obtained from the current morenosite-retgersite boundary at $31.2{ }^{\circ} \mathrm{C}$.

The results of the present study and those of Chou et al. (2002), Chou and Seal (in preparation), and Chou and Seal (in press) further confirm the conclusion of Hemingway et al. (2002) that the Gibbs free energy contribution for each water of crystallization in hydrated sulfate salts, except for the first water is about $-238.0 \mathrm{~kJ} / \mathrm{mol}$. The Gibbs free energy contribution for each water of crystallization can be calculated from the experimental results of this study for Reaction 1 by the equation:

$$
\Delta G_{\mathrm{xw}, 298.15 \mathrm{~K}}^{0}=-\left(\Delta G_{\mathrm{r}, 298.15 \mathrm{~K}}^{0}-n \Delta G_{\mathrm{f}}^{0} \mathrm{H}_{2} \mathrm{O}, 298.15 \mathrm{~K}\right) / n
$$

where $\Delta G_{\mathrm{xw}, 298.15 \mathrm{~K}}^{0}$ is the Gibbs free energy contribution for each additional water of crystallization at $298.15 \mathrm{~K}, \Delta G_{\mathrm{r}, 298 \mathrm{~K}}^{0}$ is the Gibbs free energy of the reaction at $298.15 \mathrm{~K}, \Delta G_{\mathrm{r}}^{0} \mathrm{H}_{2} \mathrm{O}, 298.15 \mathrm{~K}$ is the Gibbs free energy of formation from elements for water at $298.15 \mathrm{~K}$ (Cox et al. 1989), and $n$ is the stoichiometric coefficient for water in the dehydration reaction. For Reaction 1, 
TABLE 2. Derived equilibrium constants for reaction (1) at $0.1 \mathrm{MPa}$

\begin{tabular}{lcccc}
\hline \hline $\begin{array}{l}\text { Humidity } \\
\text { buffer }\end{array}$ & $T\left({ }^{\circ} \mathrm{C}\right) \dagger$ & $\begin{array}{c}f^{*} \mathrm{H}_{2} \mathrm{O} \\
(\mathrm{MPa}) \ddagger\end{array}$ & $\% \mathrm{RH} \S$ & $\ln \mathrm{K}$ \\
\hline $\mathrm{Kl}$ & $6.84 \pm 0.39$ & 0.0009914 & $72.86 \pm 0.11$ & $-4.930 \pm 0.025$ \\
$\mathrm{NaCl}$ & $11.81 \pm 0.24$ & 0.0013856 & $75.66 \pm 0.11$ & $-4.558 \pm 0.016$ \\
$\mathrm{NaNO}_{3}$ & $12.25 \pm 0.20$ & 0.0014265 & $77.06 \pm 0.05$ & $-4.511 \pm 0.013$ \\
$\mathrm{KBr}$ & $17.49 \pm 0.48$ & 0.0019999 & $82.13 \pm 0.09$ & $-4.109 \pm 0.030$ \\
$\mathrm{KCl}$ & $20.67 \pm 0.51$ & 0.0024386 & $85.01 \pm 0.08$ & $-3.877 \pm 0.030$ \\
\hline
\end{tabular}

$\dagger$ Equilibrium T; mean of the two values used to bracket equilibrium (see Table 1). The uncertainty listed is half of the difference of the bracket values. $\mp$ Calculated from Haar et al. (1984).

$\S$ Calculated from Greenspan (1977). Uncertainties are also based on Greenspan (1977).

$\Delta G_{\mathrm{r}, 298.15 \mathrm{~K}}^{0}$ is $8.841 \mathrm{~kJ} / \mathrm{mol}, \Delta G_{\mathrm{f}}^{0} \mathrm{H}_{2} \mathrm{O}, 298.15 \mathrm{~K}$ is $-228.6 \mathrm{~kJ} / \mathrm{mol}$ (Cox et al. 1989), and $\mathrm{n}$ is 1 , which yields a $\Delta G_{\mathrm{xw}, 298.15 \mathrm{~K}}^{0}$ of $-237.44 \mathrm{~kJ} / \mathrm{mol}$. For melanterite-rozenite and chalcanthitebonattite equilibria (Chou et al. 2002), calculated values for $\Delta G_{\mathrm{xw}, 298 \mathrm{~K}}^{0}$ are -238.34 and $-239.90 \mathrm{~kJ} / \mathrm{mol}$, respectively. The value for the goslarite-bianchite equilibria is $-238.23 \mathrm{~kJ} / \mathrm{mol}$ (Chou and Seal, in preparation), and for epsomite-hexahydrite equilibria is $-238.73 \mathrm{~kJ} / \mathrm{mol}$ (Chou and Seal 2003).

Morenosite and retgersite are relatively rare in nature. The mineralogy of selected occurrences is summarized in Table 4. The minerals can be found as weathering products of mineral deposits (Frondel and Palache 1949; King and Evans 1964; Paulo 1970; Otto and Schuerenberg 1974; Yakhontova et al. 1976; Sejkora and Rídkošil 1993), coal measures (Walker 1988), and ultramafic rocks (Bermanec et al. 2000). Typically, morenosite will be found in association with retgersite, whereas retgersite may comprise the only hydrated $\mathrm{Ni}$ sulfate in a sample or may occur with nickelhexahydrite (Table 4). The common association of retgersite with morenosite can be explained by the location of the dehydration reaction that relates the two. The equilibrium relative humidity for morenosite-retgersite re-
TABLE 3. Derived thermodynamic data for reaction 1 at $298.15 \mathrm{~K}$ and $0.1 \mathrm{MPa}$

\begin{tabular}{cccl}
\hline \hline $\begin{array}{c}\Delta G_{\mathrm{r}}^{0} \\
(\mathrm{~kJ} / \mathrm{mol})\end{array}$ & $\begin{array}{c}\Delta H_{\mathrm{r}}^{\circ} \\
(\mathrm{kJ} / \mathrm{mol})\end{array}$ & $\begin{array}{c}\Delta S_{\mathrm{r}}^{\circ} \\
{[\mathrm{J} /(\mathrm{mol} \cdot \mathrm{K})]}\end{array}$ & Reference \\
\hline $8.841 \pm 0.077$ & $52.40 \pm 0.97$ & $146.1 \pm 3.5$ & This study \\
8.901 & - & - & Schumb (1923) \\
8.827 & 52.61 & 146.9 & Bonnell and Burridge (1935) \\
8.864 & 49.13 & 135.0 & Stout et al. (1966) \\
8.648 & 51.69 & 144.4 & Wagman et al. (1982) \\
9.557 & 51.33 & 140.1 & DeKock (1982) \\
\hline
\end{tabular}

action is relatively high for a given temperature compared to other systems investigated to date (Fig. 3). Thus, morenosite should only be expected to form under cool conditions where relative humidities are high. Unless care is taken in sample collection, and analysis in the laboratory, morenosite is likely to react partly or totally to form retgersite or nickelhexahydrite.

The scarcity of these minerals in nature also can be attributed in part to the relative scarcity of $\mathrm{Ni}$ in geological environments. Coggans et al. (1999) concluded that the pore waters in the Ni-rich Copper Cliff tailings near Sudbury, Ontario (Canada) were significantly undersaturated with respect to morenosite

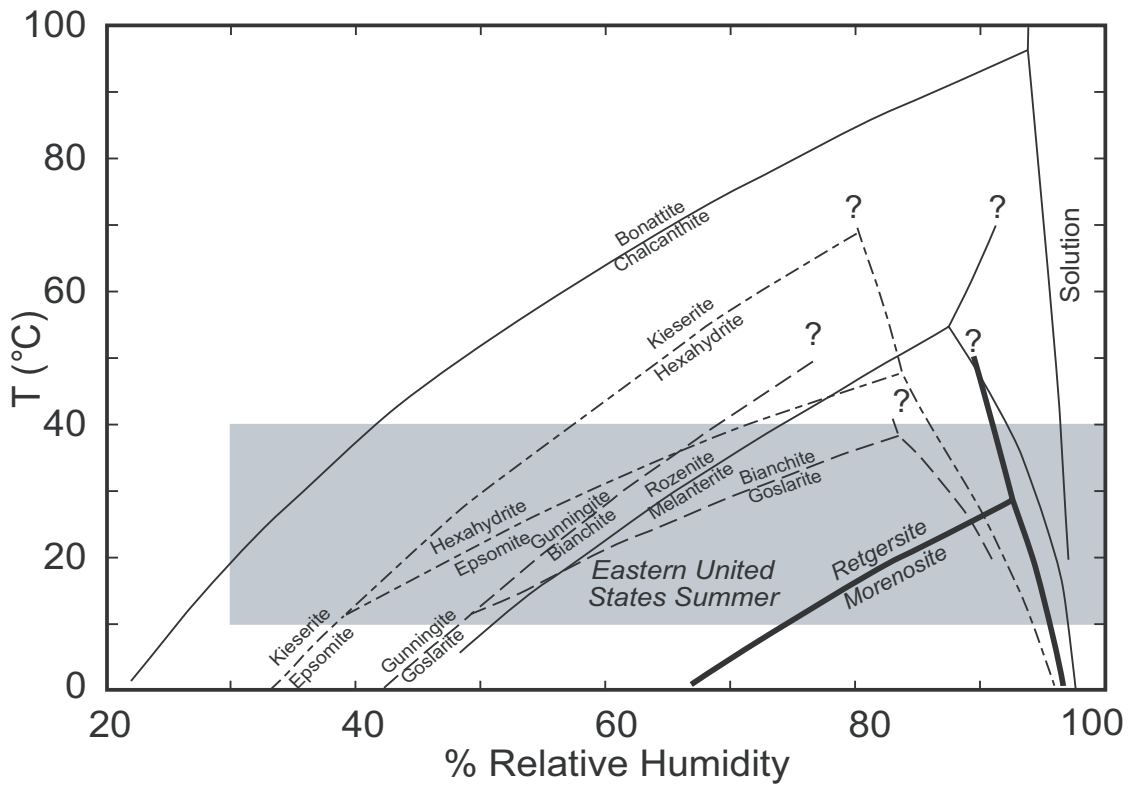

FIGURE 3. Hydrogenetic grids for hydrated metal-sulfate salts. Curves for morenosite and retgersite are from this study, those for melanterite and rozenite, and chalcanthite and bonattite are from Chou et al. (2002), those for goslarite, bianchite, and gunningite are from Chou and Seal (in preparation), and those for epsomite, hexahydrite, and kieserite are from Chou and Seal (2003). The shaded field is the general range of temperature and relative humidity during the summer in the eastern United States for comparison. 
TABLE 4. Selected mineralogy of morenosite and retgersite occurrences

\begin{tabular}{|c|c|c|c|c|c|c|}
\hline Location & Sulfates & Sulfides & Arsenates & Arsenides & Carbonates & References \\
\hline Minasragra, Peru & $\mathrm{Rt}, \mathrm{Mr}$ & $\mathrm{Pt}$ & & & & Frondel and Palache (1949) \\
\hline Cottonwood Canyon, NV & $\mathrm{Rt}$ & & & $\mathrm{Nc}$ & & Frondel and Palache (1949) \\
\hline Germany & Rt & & An & & & Frondel and Palache (1949) \\
\hline Black Forest, Germany & $\mathrm{Mr}, \mathrm{Nh}, \mathrm{Gy}, \mathrm{Me}$ & & An & & & Otto and Schuerenberg (1974) \\
\hline Noril'sk, Russia & $\mathrm{Mr}, \mathrm{Rt}, \mathrm{Nh}$ & & & & & Yakhontova et al. (1976) \\
\hline Gap Nickel mine, PA & $\mathrm{Rt}, \mathrm{Ch}$ & & & & & Frondel and Palache (1949) \\
\hline Chelmiec, Poland & $\mathrm{Rt}, \mathrm{Mr}$ & $\mathrm{Gr}$ & An & & & Paulo (1970) \\
\hline Jachymov, Czech Republic & Rt, Mr, Nh, Gy & $\mathrm{Gr}$ & An & Sk & $\mathrm{Ar}$ & Sejkora and Řídkošil (1993) \\
\hline Warwickshire, UK & & & & & & Walker (1988) \\
\hline St. Patrick's copper mine, Ireland & Mr, Gy & Py, Ap & & & & King and Evans (1964) \\
\hline Bosnia and Herzegovina & $\mathrm{Rt}, \mathrm{Nh}$ & & & & Gs & Bermanec et al. (2000) \\
\hline
\end{tabular}

Notes: $\mathrm{An}=$ annabergite $\left[\mathrm{Ni}_{3}\left(\mathrm{AsO}_{4}\right)_{2} \cdot 8 \mathrm{H}_{2} \mathrm{O}\right] ; \mathrm{Ap}=$ arsenopyrite $[\mathrm{FeAsS}] ; \mathrm{Ar}=$ aragonite $\left[\mathrm{CaCO}_{3}\right] ; \mathrm{Ch}_{=}$chalcanthite $\left[\mathrm{CuSO} \cdot 5 \mathrm{H}_{2} \mathrm{O}\right] ; \mathrm{Gr}_{2}$

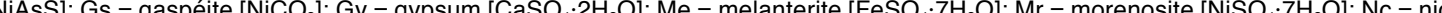
$\mathrm{Nh}=$ nickelhexahydrite $\left[\mathrm{NiSO}_{4} \cdot 6 \mathrm{H}_{2} \mathrm{O}\right] ; \mathrm{Pt}=$ patronite $\left[\mathrm{VS}_{4}\right] ; \mathrm{Py}=$ pyrite $\left[\mathrm{FeS}_{2}\right] ; \mathrm{Rt}=$ retgersite $\left[\mathrm{NiSO}_{4} \cdot 6 \mathrm{H}_{2} \mathrm{O}\right] ; \mathrm{Sk}^{2}=\mathrm{skutterudite}\left[(\mathrm{Co}, \mathrm{Ni}) \mathrm{As}{ }_{3-\mathrm{x}}\right]$.

and retgersite. However, common geochemical processes may conjoin in appropriate settings at Ni mines to cause their formation. For example, oxidation of tailings waters or other similar mine drainage will lead to the oxidation of $\mathrm{Fe}^{2+}$, thus avoiding the precipitation of melanterite or other $\mathrm{Fe}^{2+}$ sulfates, which can carry significant amounts of $\mathrm{Ni}$ in solid solution (Jambor et al. 2000). In general, $\mathrm{Ni}$ is also less likely than other metals, such as $\mathrm{Pb}$ or $\mathrm{Cu}$, to sorb on to hydrated $\mathrm{Fe}^{3+}$ oxides that may result from the oxidation of dissolved $\mathrm{Fe}^{2+}$ at $\mathrm{pH}$ values less than 6 (Smith 1999); therefore, divalent metals other than $\mathrm{Ni}$ may be preferentially removed from solution. However, it is worth noting that the sorption behavior of $\mathrm{Ni}$ and other metals is complex and depends upon a variety of factors, including the concentration of the sorbent, the concentration of the sorbate, and $\mathrm{pH}$ (Smith 1999). Finally, evaporative concentration can then cause drainage to reach saturation with respect to morenosite and (or) retgersite.

The addition of phase-equilibrium data for the system $\mathrm{NiSO}_{4}-\mathrm{H}_{2} \mathrm{O}$ improves the "hydrogenetic" grid that can be constructed for terrestrial ambient conditions by supplementing data from Chou et al. (2002), Chou and Seal (in review), and Chou and Seal (in press) (Fig. 3). The location of many of these dehydration reactions in the middle of the field of relative humidity and temperature conditions, and their rapid kinetics underscore the challenges of mineralogical characterization of samples as they relate to field conditions (Hammarstrom et al. 2002). Iron, $\mathrm{Cu}$, and $\mathrm{Zn}$ sulfate salts are common in many surficial settings, particularly around abandoned mines. Nickel may be relatively common in solid solution within these salts. The melanterite group can contain up to $46 \mathrm{~mol} \% \mathrm{Ni}$; knowledge of the maximum solubility limits of $\mathrm{Ni}$ in the hexahydrite group is limited (Jambor et al. 2000). The dissolution of these salts during summer storm events or spring-melt in snow-covered regions can have a significant impact on watersheds. The mineralogical controls on the partitioning of trace metals between dehydration products is poorly understood, as is how differential partitioning may affect surface runoff. Clearly, the location of the morenosite-retgersite dehydration reaction at higher relative humidities compared to other systems investigated should distinguish the effect of Ni relative to other trace metals such as $\mathrm{Cu}$ and $\mathrm{Zn}$ with regard to solid-solution effects among end-members in the same space groups.

\section{ACKNOWLEDGEMENTS AND DISCLAIMER}

We thank E.J. Reardon for calculating the activity of $\mathrm{H}_{2} \mathrm{O}$ in morenositeand retgersite-saturated solutions. C.E. Larsen assisted in the translation of a German article. We also thank J.M. Hammarstrom and B.S. Hemingway of U.S. Geological Survey, and J.L. Jambor for their critical review. The use of trade, product, industry, or firm names in this report is for descriptive purposes only and does not constitute endorsement by the U.S. Government.

\section{REFERENCES CITED}

Bermanec, V., Sijaric, G., Kniewald, G., and Mandarino, J.A. (2000) Gaspéite and associated Ni-rich minerals from veins in altered ultrabasic rocks from Dubostica, Bosnia and Herzegovina. Canadian Mineralogist, 38, 1371-1376.

Bonnell, D.G.R. and Burridge, L.W. (1935) The dissociation pressures of some salt hydrates. Transactions of the Faraday Society, 31, 473-478.

Chou, I.M. and Seal, R.R., II (2001a) Determination of goslarite-bianchite equilibria by the humidity buffer technique at $0.1 \mathrm{MPa}, 3144 \mathrm{p}$. Eleventh Annual V.M. Goldschmidt Conference.

(2001b) Determination of epsomite-hexahydrite equilibria by the humidity-buffer technique at 0.1 megapascal. GSA Abstracts with Programs, 33, A-403.

(2002) Acquisition and evaluation of thermodynamic data for morenosite-retgersite equilibria at $0.1 \mathrm{MPa}$. American Geophysical Union Transactions, 83, F1498.

(2003) Determination of epsomite-hexahydrite equilibria by the humiditybuffer technique at $0.1 \mathrm{MPa}$ with implications for phase equilibria in the system $\mathrm{MgSO}_{4}-\mathrm{H}_{2} \mathrm{O}$. Astrobiology, in press.

Chou, I.M., Seal, R.R., II, and Hemingway, B.S. (1998a) Humidity buffers and their application to the studies of dehydration reactions of sulfate salts at $0.1 \mathrm{MPa}$. American Geophysical Union Transactions, 79, S364.

- (1998b) Relative humidity-temperature relations of dehydration reactions for hydrated salts: a new experimental approach. GSAAbstracts with Programs, 30, A129.

(1999) Determination of melanterite-rozenite and chalcanthite-bonattite equilibria by the humidity buffer technique at $0.1 \mathrm{MPa}$. Ninth Annual V.M Goldschmidt Conference, 54-55.

(2000) Low-temperature thermodynamic properties of hydrated ferrous sulfates: Experimental results and evaluation of published data. GSAAbstracts with Programs, 32, A-108.

(2002) Determination of melanterite-rozenite and chalcanthite-bonattite equilibria by humidity measurements at $0.1 \mathrm{MPa}$. American Mineralogist, 87, 108-114.

Coggans, C.J., Blowes, D.W., Robertson, W.D., and Jambor, J.L. (1999) The hydrogeochemistry of a nickel-mine tailings impoundment-Copper Cliff, Ontario. Reviews in Economic Geology, 6B, 447-465.

Cox, J.D., Wagman, D.D., and Medvedev, V.A. (1989) CODATA key values for thermodynamics, 271 p. Hemisphere, New York.

Dagenhart, T.V., Jr. (1980) The acid mine drainage of Contrary Creek, Louisa County, Virginia: Factors causing variations in stream water chemistry. MSc thesis, University of Virginia, Charlottesville, Virginia. $215 \mathrm{p}$.

DeKock, C.W. (1982) Thermodynamic properties of selected transition metal sulphates and their hydrates. U.S. Bureau of Mines Information Circular, 9810, 1-45.

Frondel, C. and Palache, C. (1949) Retgersite, $\mathrm{NiSO}_{4} \cdot 6 \mathrm{H}_{2} \mathrm{O}$, a new mineral. American Mineralogist, 34, 188-194.

Greenspan, L. (1977) Humidity fixed points of binary saturated aqueous solutions. Journal of Research of the National Bureau of Standards-A. Physics and Chemistry, B1A, 89-96.

Haar, L., Gallagher, J.S., and Kelly, G.S. (1984) NBS/NRC steam tables: Thermodynamic and transport properties and computer programs for vapor and liquid states of water in SI units, 320 p. Hemisphere, Washington, D.C. 
Hammarstrom, J.M., Seal, R.R., II, Meier, A.L., and Kornfeld, J.M. (2000) Secondary sulfate minerals associated with acid drainage in the eastern United States: recycling of metal and acidity in surficial environments. GSA Abstracts with Programs, 32, A-180.

Hemingway, B.S., Seal, R.R., II, and Chou, I-M. (2002) Thermodynamic data for modeling acid mine drainage problems. I. Compilation and estimation of data for selected soluble iron-sulfate minerals. U.S. Geological Survey Open File Report 02-161.

Jambor, J.L., Nordstrom, D.K., and Alpers, C.N. (2000) Metal-sulfate salts from sulfide mineral oxidation. In C.N. Alpers, J.L. Jambor, and D.K. Nordstrom, Eds., Sulfate minerals: Crystallography, geochemistry, and environmental significance, 40, 305-350. Reviews in Mineralogy and Geochemistry, Mineralogical Society of America, Washington, D.C.

Janjic, S., Gakovic, M., Dordevic, D., and Bugarski, P. (1980) Nickeloan hexahydrite from Drovskovac near Vares, Bosnia, Yugoslavia. Glasnik Prirodjackog Muzeja u Beogradu, Ser. A, 34, 5-11 (Chem. Abstracts 95:46247a).

King, R.J. and Evans, A.M. (1964) An occurrence of morenosite in Ireland. Mineralogical Magazine, 33, 1110-1113.

Linke, W.F. and Seidell, A. (1965) Solubility of inorganic and organic compounds. Vol. 2, $4^{\text {th }}$ edition, 1914 p. American Chemical Society, Washington, D.C.

Malinin, A.A., Drakin, S.I., and Ankudimov, A.G. (1977) Measurement of equilibrium vapour pressure in stepwise dehydration by using saturated reference solutions. Russian Journal of Physical Chemistry, No. 6. Translated from Zhurnal Fizichekoi Khimii, 51, 1557-1558.

(1979) Equilibrium dehydration pressures of salt crystal hydrates. Russian Journal of Physical Chemistry, 53, 755. Translated from Zhurnal Fizichekoi Khimii, 53, 1332-1333 (1979).

Otto, J. and Schuerenberg, H. (1974) New mineral finds in the southern Black Forest. Aufschluss, 25, 205-211 (in German).

Paulo, A. (1970) On the formation of retgersite from Chelmiec. Mineralogia Polonica,
$1,37-45$.

Polyanskii, N.G., Gorbunov, G.V., and Polyanskaya, N.L. (1976) Methods of studying ion-exchange resins. Izdatelstvo Khimiya, Moscow.

Reardon, E.J. (1989) Ion interaction model applied to equilibria in the $\mathrm{NiSO}_{4}-\mathrm{H}_{2} \mathrm{SO}_{4}$ $\mathrm{H}_{2} \mathrm{O}$ system. Journal of Physical Chemistry, 93, 4630-4636.

Schumb, W.C. (1923) The dissociation pressures of certain salt hydrates by the gas-current saturation method. Journal of American Chemical Society, 45, 342-354.

Sejkora, J. and Řídkǒsil, T. (1993) Retgersite from Jáchymov, Krusné hory Mountains, Czech Republic. Neues Jahrbuch für Mineralogie Monatshefte, 1993, 292-400.

Smith, K.S. (1999) Metal sorption on mineral surfaces: an overview with examples relating to mineral deposits. Reviews in Economic Geology, 6A, 161-182.

Stout, J.W., Archibald, R.C., Brodale, G.E., and Giauque, W.F. (1966) Heat and entropy of hydration of $\alpha-\mathrm{NiSO}_{4} \cdot 6 \mathrm{H}_{2} \mathrm{O}$ to $\mathrm{NiSO}_{4} \cdot 7 \mathrm{H}_{2} \mathrm{O}$. Their low-temperature heat capacities. The Journal of Chemical Physics, 44, 405-409.

Wagman, D.D., Evans, W.H., Parker, V.B., Schumm, R.H., Halow, I., Bailey, S.M., Churney, K.L., and Nuttal, R.L. (1982) The NBS tables of chemical thermodynamic properties. Selected values for inorganic and $C_{1}$ and $C_{2}$ organic substances in SI units. Journal of Physical Chemistry Reference Data, Vol. 11, supplement no. 2, $392 \mathrm{p}$.

Walker, D.R.G. (1988) Retgersite, $\mathrm{NiSO}_{4} \cdot 6 \mathrm{H}_{2} \mathrm{O}$ : a new British occurrence from Warwickshire. Journal of the Russell Society, 2, 29-30.

Yakhontova, L.K., Sidorenko, G.A., Stolyarova, T.I., Plyusnina, I.I., and Ivanova, T.L. (1976) Nickel-containing sulfates from the oxidation of the Noril'sk deposits. Zapiski Vsesoyuznogo Mineralogicheskogo Obshchestva, 105, 710-720 (in Russian).

MANUSCRIPT RECEIVED DECEMBER 9, 2002

MANUSCRIPT ACCEPTED JUNE 18, 2003

MANUSCRIPT HANDLED BY JOHN JAMBOR 